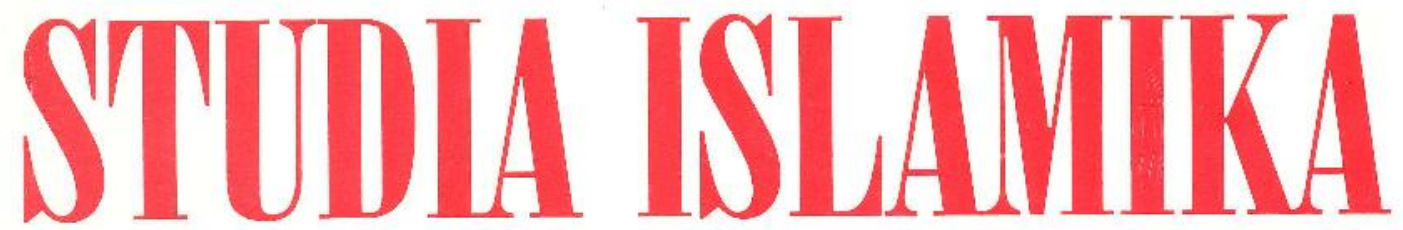

INDONESIAN JOURNAL FOR ISLAMIC STUDIES

Volume I, Number 2, 1994

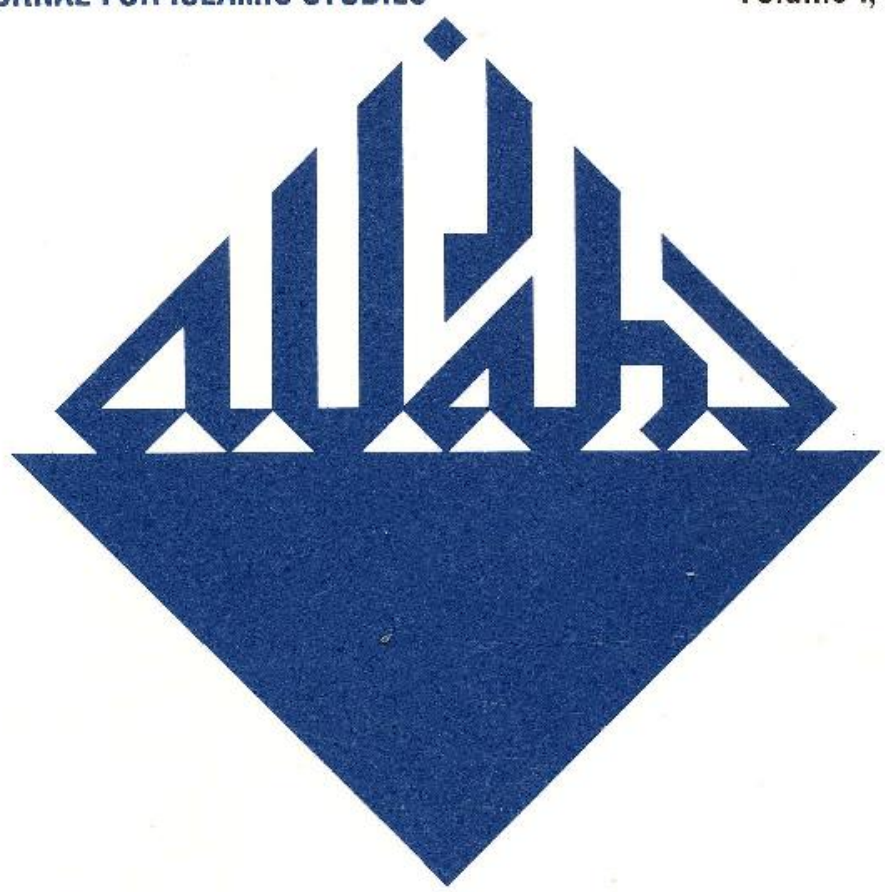

ISLAM AND PARTY POLITICS IN RURAL JAVA

Bambang Pranowo

THE ROLE OF ISLAM IN INDONESIAN AND ALGERIAN HISTORY:

A Comparative Analysis

Johan H. Meuleman

GUARDING THE FAITH OF THE UMMAH:

Religio-Intellectual Journey of Mohammad Rasjidi

\title{
Azyumardi Azra
}




\section{STIDDLA ISLAMIKA}

Indonesian Journal for Islamic Studies

Volume I, No. 2, 1994

EDITORLAL BOARD:

Harun Nasution

Mastubu

M. Quraisb Shibab

A. Aziz Dablan

M. Satria Effendi

Nabilab Lubis

M. Yunan Yusuf

Komaruddin Hidayat

Dien Syamsuddin

Muslim Nasution

Wabib $M u^{\prime}$ thi

EDITOR IN CHIEF:

Azyumardi Azra

EDITORS:

Saiful Muzani

Hendro Prasetyo

Joban H. Meuleman

Nurul Fajri

Badri Yatim

ASSISTANTS TO THE EDITOR:

Arif Subban

Mucblis Ainurrafik

ENGLISH LANGUAGE ADVISOR:

Judith M. Dent

COVER DESIGNER:

S. Prinka

STUDIA ISLAMIKA (ISSN 0215-0492) is a Journal published quarterly by Institut Agama Islam Negeri (IAIN, The State Institute for Islamic Studies) Syarif Hidayatullah, Jakarta, (STT DEPPEN No. 129/SK/DITJEN/PPG/STT/1976) and sponsored by the Department of Religious Affairs of the Republic of Indonesia. It specializes in Indonesian Islamic studies, and is intended to communicate original researches and current issues on the subject. This journal warmly welcomes contributions from scholars of related disciplines.

All articles published do not necessarily represent the views of the journal, or other institutions to which it is affiliated. They are solely the views of the authors. 


\section{Bambang Pranowo}

\section{Islam and Party Politics in Rural Java}

Abstraksi: Pemerintab Orde Baru sangat menekankan stabilitas politik demi pembangunan ekonomi. Hal ini antara lain ditandai dengan kebijaksanaan politik "massa mengambang" (floating mass), di mana partai politik banya dibolebkan mempunyai pengurus sampai di tingkat kabupaten, tidak sampai tingkat kecamatan, apalagi pedesaan. Perubahan besar kebijakan politik ini merupakan depolitisasi penuh atas masyarakat pedesaan, dan agaknya berpengaruh terhadap polarisasi kebidupan keagamaan di pedesaan.

Tulisan ini mencoba memaparkan bagaimana dampak de-politisasi massa terhadap polarisasi kebidupan keagamaan, santri-abangan, di pedesaan. Kemudian, apakab kategori dikotomis santri-abangan untuk memahami kebidupan keagamaan di Jawa masib relevan.

Dari penelitiannya di desa Tegalroso (bukan nama sebenarnya), Magelang, Jawa Tengah, penulis menemukan, depolitisasi atas masyarakat pedesaan telab mengurangi tingkat polarisasi dalam kebidupan keagamaan secara substansial. Masyarakat menjadi lebih kuat Islamnya, dan kegiatan keislaman menjadi concern semua orang lepas dari afiliasi politik mereka. Islam sekarang mendapatkan kembali daya tarik dan fungsinya bagi seluruh orang-orang desa. Semua warga desa sekarang mengaku dirinya Muslim. Karena itu, pendekatan dikotomis santri-abangan tidak lagi relevan digunakan untuk memabami kehidupan kegamaan di Jawa. 


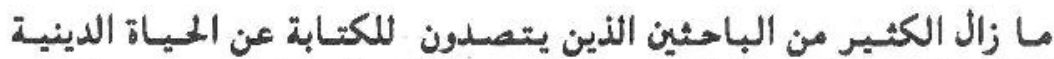

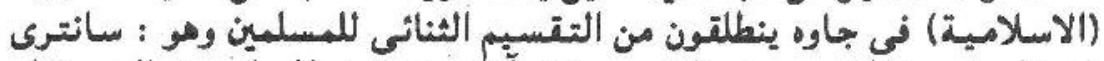

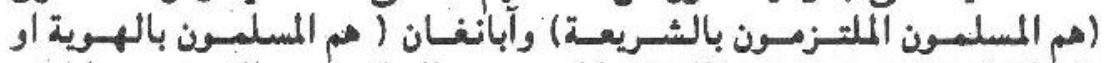

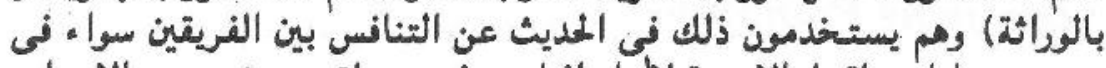

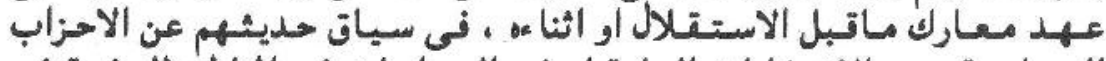

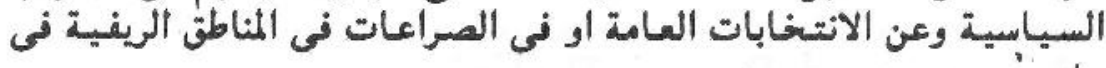

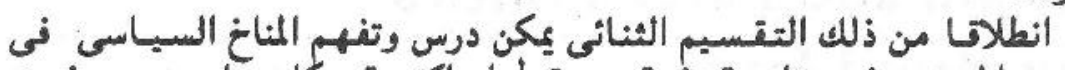

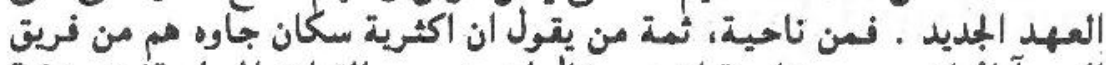

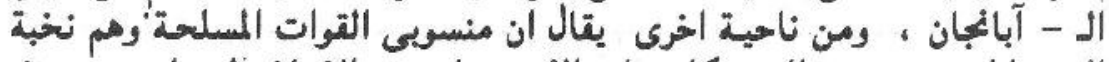

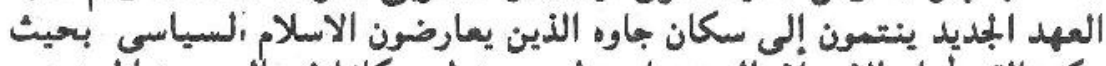

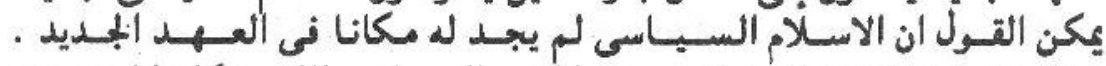

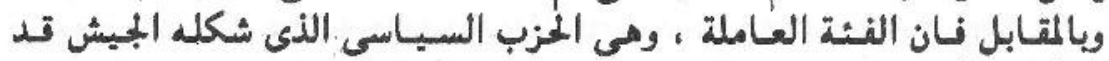

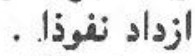

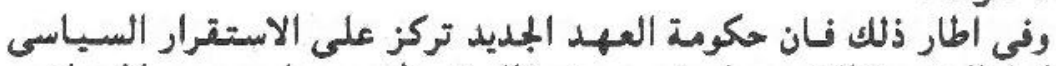

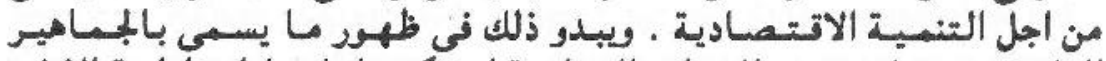

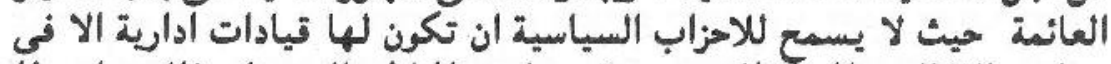

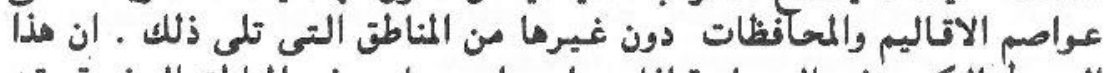

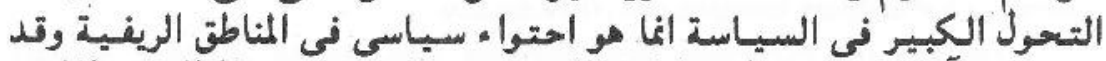

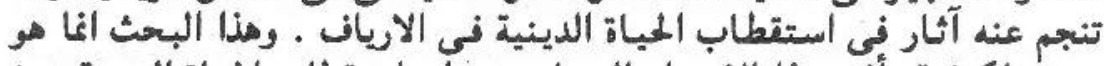

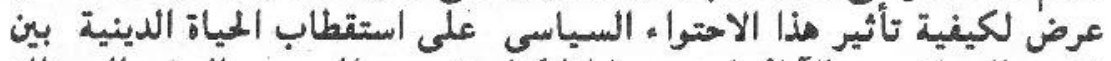

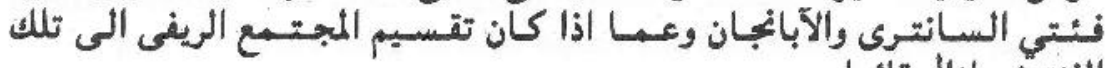

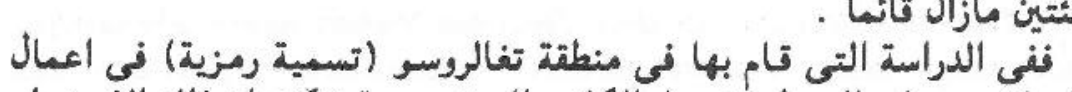

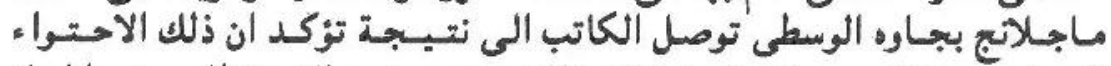

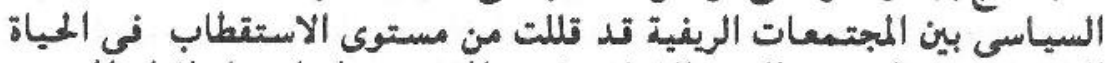

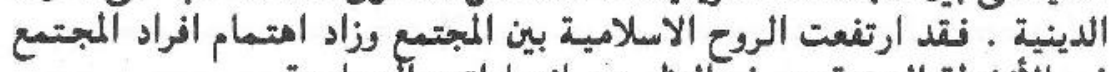

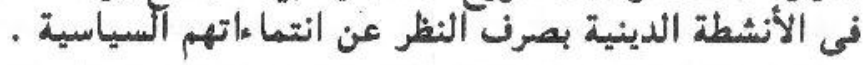


$\Lambda_{\text {Javanese society has consistently linked variations in Is- }}^{\text {Jamic orthodoxy to differences in socio-economic class, po- }}$ litical behavior and social conflict. The basic distinction between pious Muslims (santri) and nominal Muslims (abangan) has been used, for example, to explain patterns of elite competition in the pre-war Japanese and independence eras (Benda, 1958); political party mobilization and voting patterns in the general election of 1955 (Feith, 1957); and the basis of conflict in rural Java (Lyon, 1970).

The abortive coup allegedly masterminded by the Indonesian Communist Party (PKI) in 1965 and the massacre which followed, as well as the socio-political development in Indonesia under the New Order government, have also been explained in terms of the santri and abangan rifts in Javanese rural society (Mackie, 1982:124). Furthermore, Ricklefs suggests that the majority of the Javanese are abangan (Ricklefs, 1979:127), whilst according to Samson most Indonesian military leaders, many of whom are themselves Javanese, oppose a politically powerful Islam and are unalterably suspicious of santri intentions (Samson, 1971: 546-547). This also explains the success of Golkar (Golongan Karya, Functional Group), the military-backed political party, in the general election of 1971 in Javanese community areas (Ward, 1974:172) and in the general elections of 1977, 1982 and 1987 (Suryadinata, 1988:271). These observers, in short, argue that the polarization between santri and abangan under the New Order government continues to be as it was under the Old Order.

However, seen from the historical perspective, we actually find that the relationship between that which is categorized as Javanese santri and abangan has varied greatly over time (Pigeaud 1967; Ricklefs 1975). There were also times when Islam functioned as the sole all-embracing power and provided a sense of unity and identity for almost all of Java, such as during the period of the Java War against the Dutch (1825-1830) and the first decade of the Sarekat Islam movement when Muslim traders, workers in cities, kyais and even some priyayis (Javanese aristocrats), but above all peasants, were drawn into this first political mass movement in colonial Indonesia (Benda, 1958:42). 
Based on this historical perspective, we must presume that the tremendous changes in socio-political life under the New Order government will have an effect on Javanese religious life. The 'floating mass' policy, for example, under which political parties are not allowed to organize executive boards below the regency level, has resulted in an almost complete depoliticization of rural people. Thus, it is conceivable that such a rural depoliticization may be reducing communal cleavages and religious polarization (see Mackie, 1982:126).

In this essay I shall discuss the decrease of religious polarization as a result of depoliticization at the rural level which, in turn, results in a blurring of the distinctions between santri and abangan. This is a 'by product' of a field study which I conducted in Tegalroso (a pseudonym), a dry land village on the west slope of Mount Merbabu in the Regency of Magelang, Central Java, during July to December 1987.

Politically, before the banning of the Indonesian Communist Party (PKI) in 1966, this village was known as the stronghold of the PKI and the Indonesian Nationalist Party (PNI). Socially, the village was notorious for being crime-ridden, gambling and theft being prevalent, and, religiously, most people of the village, observed from outside, appear to fall into the category of 'nominal Muslims', labeled by many as abangan (Geertz 1960, Lyon 1970, Ward 1974).

\section{The Pre-colonial and Colonial Periods}

Although Islam first came to the Magelang area in the second half of the 15 th century, its impact has been uneven. In many villages Islamic teachings have become a major framework for daily life. But in some villages pre-Islamic elements are still dominant. Thus there are variations in religious practices from one village to another. Moreover, national and local level politics have had an effect on local religious practices.

As we shall see, the history of Islam in Tegalroso is the history of a continuing process of Islamization. All the indigenous people in Tegalroso claim to be Muslims. The only self-confessed nonMuslim among all the inhabitants (a total of 1,793 in November 1987) is a primary school teacher, a Christian from Yogyakarta. 
Yet, according to their own perceptions, the villagers have become more committed Muslims in the last two decades. They are now, in their own terms 'langkung saè Islamipun' (better Muslims).

Information provided by village informants in addition to genealogical knowledge gathered from elderly villagers, leads to the following periodization of the history of religiosity in the village: 1) before and during the colonial period; 2) from independence to 1965 (the Old Order period); 3) the New Order period. In each period, Islam in Tegalroso has taken on certain specific characteristics and the last period has witnessed an increasing influence of santri religious culture. It can be presumed that long before Dutch colonialism Islam had spread to all villages in the Magelang area, including Tegalroso, although no one in the village knows exactly when Islam first arrived. There is evidence that $\mathrm{Ki}$ Suroso, the cikal bakal (village founder), was a Muslim since his grave stands in the Calonan (a hamlet within Tegalroso village) cemetery. If he had been a Hindu or a Buddhist his corpse would have been cremated and hence there would be no grave. This assumption is supported by the fact that Ki Soroyudo's grave is arranged in an Islamic manner, the stone at the head of the tomb being placed to the north, with his legs towards the south. This indicates that the corpse was laid out facing the kabab in Mecca which Muslims face to pray.

There is insufficient material on $\mathrm{Ki}$ Suroso to tell us much about his religious beliefs, partly because he had no children to keep his memory alive. It is likely that his beliefs were much colored by pre-Islamic elements and, at the same time, were mystical in their theological content, as was the case for Islam elsewhere in Java during this early period (Ricklefs, 1979:107).

After the Java War (1825-1830) for example, when Javanese society fell increasingly under the sway of Dutch colonial power, Ki Surojoyo, one of Prince Diponegoro's soldiers who fled from the Yogyakarta area, found Tegalroso to be a safe refuge. Amongst other things Ki Surojoyo was a religious teacher in the village. His teaching apparently emphasized the mystical rather than the ritual dimensions of Islam. For example, he taught the importance of performing dhikr (the recitation of Allâh's names) at midnight, a practice continued by the present lurab, a fourth generation descendant of Ki Surojoyo. The five daily prayers now central to 
orthodox Muslims were less significant in this period. Even according to an orthodox Islamic movement such as Muhammadiyah, in order to be regarded as a Muslim one merely needs to affirm one's faith: "There is no god but Allah, the One God, and Mohammad is His Messenger". According to mBah Parto Gèni, who is now in his eighties, in the second decade of this century Tegalroso was famous in the surrounding villages because of the presence of a well known mystic, mBah Rèkso Joyo. MBah Parto stated that $\mathrm{mBah}$ Rekso Joyo was a follower of Syeh Siti Jenar, an Islamic mystic and teacher said to have been executed by the wali songo (nine saints), for having taught about the unity between man and God (manunggaling kawulo Gusti, or wabdâniyab) (Ricklefs, 1979). During this time people traveled great distances to visit Tegalroso in order to become disciples of mBah Rèkso, to seek his help in curing illnesses or to solve personal problems. He died in 1919.

At about the same time a man believed to be a walî (saint), $\mathrm{mBah}$ Hasan Muslim, lived in the neighboring village of Sidorèjo, to the west of Tegalroso. MBah Hasan was widely believed to possess the power to perform karâmah (saintly miracles) and thought to be especially adept at erecting dams (bèndungan) in the steep, dry areas on the western slopes of Mount Merbabu. Hence people called him the wali bèndungan. MBah Hasan Muslim died in 1921, and since 1964 his death has been commemorated annually in the month of Mulud (month of the birth of the Prophet Muhammad). This commemoration (kbawl) is attended by thousands of people from all the villages in the area and a road in Tegal Rejo is named after him. One of mBah Muslim's disciples, Abdullah Ahmad or mBah Dul, currently approximately 105 years old, still lives in the village of Ngabean. One of his disciples, the dukun Pak Rajiman, lives in Tegalroso.

After the deaths of mBah Rekso Joyo and $\mathrm{mBah}$ Hasan Muslim, Tegalroso gained notoriety as a center for gamblers, thieves and robbers. Even the sons of Rono Jayadi, the Lurab of Tegalroso from 1910 to 1926 , were involved in criminal activities. Since then, in the words of $\mathrm{mBah}$ Parto Geni: tiyang Tegalroso soyo tebih saking agami (Tegalroso people have moved farther and farther away from religious teachings). That is why no one from Tegalroso was allowed to stand in the Lurab election held in 1928. 
Subsequent lurabs were therefore always selected from candidates who came from outside Tegalroso.

During the Japanese occupation (1942-1945), a period characterized by ubiquitous hardship and famine, there were apparently no important changes in the socio-religious life of Tegalroso people. Tegalroso remained notorious for crime. Nevertheless, there were no sharp distinctions made between pious Muslims or santri and Islam Kejawèn. According to some village elders, during this period many villagers often attended pengajian (open religious lectures) at either the Payaman Pesantren (led by Kyai Syiroj) or the Watu Congol Pesantren (led by Kyai Dalhar). In these pengajian Kyai Syiroj and Kyai Dalhar, both kyais believed to have been blessed with karamah, led the congregations in reciting prayers to request God's help in preventing calamities. "Although many of us did not conduct the five daily prayers (dèrèng nglampabi), we respected the Kyais. Thanks to the Kyais' prayers, we were protected by God and no one here was forced to be a romusha (laborers exploited by the Japanese)", stated mBah Sanggup, a villager in his eighties.

As this account shows, the villagers associate the term religion only with Islam and committing crimes is seen as evidence that someone is tèbih saking agami (far from religion). Thus, when people talk about Islam they tend to emphasize its moral rather than its ritual aspects. The fact that even those who did not pray regularly attended pengajian indicates that most villagers regarded the Kyais as their spiritual leaders.

\section{From Independence to 1965}

Conditions did not change significantly in the first few years after the proclamation of Independence on 17 August 1945. During the first years of the war of independence (1945-1950) thousands of guerrilla fighters from all over Java went to Parakan, about $22 \mathrm{Km}$ northwest of Magelang, to obtain invulnerability from $\mathrm{mBah}$ Subeki, a famous Kyai. People believed that bambu runcing (sharpened bamboo spears) would be filled with magic when blessed by mBah Subeki, who was therefore called Kyai Bambu Runcing (see Soejatno, 1974:104 and Zuhri, 1987: 278-284). 
Pak Prapto, the father of the present lurab of Tegalroso, says that he and many other Tegalroso people -including those who then became leaders of the PKI in Tegalroso- also went to Parakan for mBah Subeki's prayers. "There was no conflict between Pak Parto Geni (an ex-PKI member), Pak Sukur (an NU member) and I (an ex-PNI member) in religious matters. We even went to mBah Subeki together" Pak Prapto remarked. This again shows that, in the first years of independence, there were no sharp distinctions among the villagers on the basis of their religious practices.

In the 1920 s there were significant differences of opinion regarding ideologies -Islam, Marxism and Nationalism- each having their own advocates. Yet these splits were largely restricted to intellectuals or literate people in urban areas, and thus had a relatively insignificant impact on socio-religious life at the village level. In the 1920 s even the Communist Party (PKI) still utilized Islamic labels i.e. Sarekat Islam Merab or "Red SI" (Ricklefs, 1987:166).

In November 1945, just three months after the proclamation of independence, a multi-party system was created (Feith, 1966:22). The three largest political parties which emerged were: the Nationalist Party (PNI), the Masjumi Muslim Party and the Communist Party (PKI), each articulating one of the three major ideological tendencies of the 1920s. After independence these parties were given almost unlimited freedom to mobilize supporters and were soon involved in strenuous competition for followers. As a result, political tension occurred not only among elites at the center of power, but also among people at the village level.

On 18 September 1948 the PKI launched a rebellion against the government. This rebellion was centered on Madiun in East Java, but was crushed in a relatively short time by pro-government forces. About $200 \mathrm{PKI}$ and other leftist leaders remaining in Yogyakarta were arrested, being accused of involvement in the rebellion.

On 18 December 1948 the Dutch launched a military attack agairist Indonesia, known as the 'second police action' (the 'first police action' occurred in 1947) (Ricklefs, 1987:217-218). 
Just before Yogyakarta was taken by the Dutch, the arrested PKI and leftist leaders escaped from Wirogunan Prison, Yogyakarta. Some of them, including Suparna Sastra Diraja, then went to the Cepogo plantation area on the slopes of Mount Merapi and Mount Merbabu to join the remnants of the PKI rebels led by Sumarto and Sutrisno who had built a military base for 'revolutionary struggle'. The PKI local rebels, then better known as Gerombolan MMC (the Merapi Merbabu Complex Gang), decided to demolish the Cepogo plantation. Sastradiraja notes that more than 45 million coffee, tea and other trees were chopped down, and the land was distributed to the peasants (Sastradiraja, 1988:138).

In the eyes of the Government and non-PKI parties this action was illegal, for plantations like Cepogo were to be controlled by the Government rather than by any particular group. But the action attracted sympathy for the PKI from many villagers who lived on the slopes of Mount Merapi and Mount Merbabu. In addition it was during these years that the PKI began to gain a large following in Tegalroso. "Many people here were attracted to the PKI because its promise to distribute land to the peasants who utilized it had already been fulfilled in Cepogo", an ex-PKI member declared.

The PNI was also successful in mobilizing support among the villagers in Tegalroso, in particular because many people identified the party with Bung Karno (popular nickname for former President Sukarno), the founder of the PNI, who was much admired by most Javanese. Pak Prapto, the carik (chief clerk) of Tegalroso from 1929 to 1974 and formerly a PNI activist, stated that, in order to attract people to support the PNI, he and the other activists in the party needed only to say "Sampean ndèrèk Bung Karno punapa mbotèn? Menawi ndèrèk Bung Karno lha inggib tumut partainipun, inggib puniko PNI" (Do you follow Bung Karno or not? If you follow Bung Karno choose his party, the PNI).

Most villagers were not interested in supporting Islamic parties such as Masjumi and the Nahdlatul Ulama (NU). Regarding Masjumi, this was partly because it had always been associated with the Darul Islam rebellion which centered on West Java (see Ricklefs, 1987:215-216). As for the NU, the more abstract religious campaigns propagated by this party were less appealing. Pak Jadi, 
PNI activist at the time, still remembers that a part of Masjumi's propaganda was: "Sopo numpak sepur lungo nyang Betawi, sopo pèngin makmur milibo Masjumi" (Those who want to go by train need just go to Betawi, those who want to prosper should just choose Masjumi). Pak Jadi remarked: "How could Masjumi bring prosperity when it was Masjumi supporters who launched rebellions in West Java and Sumatra?"

As for the NU, Pak Jadi said that it was too busy with prayers (donga) and it had always mixed religion and politics. "I myself am a Muslim. But I don't like religion being mixed with politics". He also mentioned some NU activists from Calonan who, according to him, were active in the NU just because they wanted to become religious people and to do good deeds, not to achieve high positions.

On the other hand, in the eyes of NU supporters, most people in Tegalroso were still distant from religion and this is why they did not support the kyais' party. "If they were really good Muslims they would not have gambled or robbed and they would have always followed the advice of the kyais", according to Pak Syukur, an NU member.

This shows that the presence of political parties in the village made a significant impact on socio-religious life. Many of those who could be categorized as more pious Muslims supported the NU, while the rest supported the PKI or the PNI. In other words, the presence of political parties sharpened the distinctions between the santri or the pious, and adherents of Islam Kejawèn.

Since almost all kyais in the area around Tegalroso were supporters of the NU, they were regarded by the villagers as almost identical with this party. This resulted in a non-NU movement, in particular involving PKI supporters, away from the leadership of the of the kyais and caused the rise of local secular party leaders such as Pak Jaror from the PNI and Pak Argo from the PKI. The PKI and the PNI were politically very strong in Tegalroso until the general election of 1955. At the same time the village remained notorious for crime. Two of the biggest events in local memories were the killing of two police officers patrolling the village, and a plot by a man named Bènggol to rob a pawnshop in Sentolo, Yogyakarta. The killing of the two police officers, Sukro and Sukur, was carried out in 1949 by a gang led by Budar, because 
they feared the police were coming to arrest them. This bloody affair resulted in the arrest of more than ten villagers from Tegalroso, and Budar, the leader and an MMC Communist activist, was shot to death in front of his house. The place where Sukro and Sukur were buried, at a cliff west of the Tegalroso hamlet cemetery, is now believed to be haunted.

The robbery of the Sentolo pawnshop in October 1954 was even more traumatic. In this affair Benggol and his gang robbed more than 50 kilograms of gold jewelry, and distributed it to fellow Tegalrosoans for safe-keeping. Five days after the robbery, before sunrise, the villagers found their hamlet surrounded by soldiers. They were prohibited from leaving their houses during the day, and police officers, aided by the soldiers, searched every house in the neighborhood.

Bènggol and his gang (including Wadi, Harjo, Tarmo, Sukit and Joyo Marto) were eventually captured at 4 pm after a long search. According to the villagers the capture took a long time because the thieves, especially Benggol, were believed to have the capacity to make themselves invisible. Pak Prapto, the carik (chief clerk) at the time, states that Benggol was finally captured because among the soldiers was one named Samani, who was believed to have similar magical abilities. Bènggol, Wadi and Harjo were each jailed for five years; Tarmo, Sukit and Joyo Marto for two years.

These affairs increased the notoriety of Tegalroso. They took place in a time of increasing PKI influence in the village. Although no one knows who was involved, many informants recall that up until the first General Election of 1955 the PKI was very strong in the hamlets of Gambas, Tegalroso and Jagang; the PNI in the hamlets of Tegal Watu and Playon; while the only Islamic party in the village, the NU, had many supporters in the hamlets of Calonan and Petung. The PNI, which was backed by the village governmental apparatus and primarily the lurah, finally won the general election although only with a slim lead over the PKI.

The years after the general election of 1955 were characterized by continual crises in national political life. But it was clear that the PKI was becoming stronger and stronger. Masjumi and the Socialist Indonesia Party (PSI), the PKI's strongest opponents, were both banned in 1960 due to the involvement of their leadership in the PRRI rebellion (Pemerintah Revolusioner Republik Indonesia - 
Revolutionary Government of the Indonesian Republic). Subsequently state policy was devoted to the implementation of Sukarno's doctrine of NASAKOM (Nasionalis, Agama dan Komunis or Nationalism, Religion and Communism). This basically meant that all political parties but primarily the PNI, NU and PKI, would play a role in government at all levels. This policy resulted in the ever increasing influence of the PKI throughout the country (Ricklefs, 1987:256:257).

Although in theory Nasakom was intended to unite the supporters of the various political parties, in practice it sharpened the distinctions among people on the basis of party affiliation. In Tegalroso, the decisive impact of Nasakom policy upon village life was described by some informants in the following terms:

\begin{abstract}
The hamlets of Tegal Watu and Playon were formerly known as basis PNI (PNI strongholds); the hamlets of Calonan and Peting were basis $N U$; while the hamlets of Gambas, Tegalroso and Jagang were widely known as basis PKI. Each group boasted their own party and viewed the others as enemies. PNI and PKI people branded NU members as religious fanatics. PKI members boasted that theirs was the only revolutionary party and saw PNI and NU people as defenders of the landlords. Harmony among people broke down. The exchange of insults among groups was common.
\end{abstract}

The term agama (religion) was therefore associated more and more only with those who supported the religious party, the NU. Yet, in fact, non-NU members continued to call themselves Muslims. Pak Juremi, an NU member, jokingly stated: "They were still Muslims but their Islam was Islam Biren. 'Bi' from the word rabi (to get married) and 'rèn' form lèrèn (finish). Thus, their Islam was bubar rabi terus lèrèn (Islam by marriage ceremony only, thereafter the marriage then ended)". He continued: "They still needed religion, but only when they held slametan (religious communal feasts) and when one of their relatives died."

So, in the eyes of the villagers, the penetration of political parties into village life and the compartmentalization of people based on political party affiliation during the Nasakom era, resulted in a sharpening of the cleavage between the more and the less pious villagers. This situation remained so until 1965. 


\section{Islam Under the New Order}

The attempted Communist coup of 1965 marked a watershed in modern Indonesian history (Johns, 1986:215), and this also holds for the socio-religious conditions in Tegalroso. In his book Religion and Politics in Rural Central Java, Robert Jay says that the existence of two mosques in Kelurahan Kebonsari, was "a clear enough indication of the strength of orthodoxy in the community" (Jay, 1963:32). The substantial number of large and small mosques in Tegalroso might lead us to similarly characterize the village as strongly orthodox (santri) for here there are three mosques located in the hamlets of Playon, Calonan and Tegal Watu, and four langgars (prayer houses) situated in the hamlets of Gambas, Tegalroso Jagang and Petung. However, most of these mosques and langgars are relatively new. Therefore, according to Jay, the orthodoxy of Islam in Tegalroso is a recent phenomenon.

The ever-increasing influence of santri religious culture upon village life in the years since 1965, which brought about the foundation of new langgars and mosques, can be better understood by placing the phenomenon of religious resurgence in its sociopolitical context. Yet the foundation of new langgars and mosques is not merely a reflection of the fulfillment of a political need, but also an indicator of a genuine religious resurgence among the villagers.

In the immediate aftermath of the events of 1965, the identification of the PKI as an atheist group was very strong. For example, Soeharto, commander of the Army at the time, described the 30 September movement of the PKI as an atheist movement which had to be crushed and was not to be allowed to survive in a Pancasila-based state. The military leadership also argued that eradicating the roots of Communist influence by crushing the PKI, should be followed up by efforts to promote mental development in order to inculcate Pancasila, religious morality and belief in God. Such statements soon echoed throughout the country and were taken up by most non-PKI leaders.

It is understandable that in this atmosphere religion became an important matter for every citizen. For many villagers conducting prayers and attending places of worship became matters of great urgency in order to confirm their lack of association with the PKI. 
As Geertz notes, the great waves of anti-Communism meant that not to have a state-recognized religious affiliation was to run the risk of being branded an atheist, hence also a communist and thus a candidate for death or imprisonment (Geertz, 1972:69).

But Geertz also describes: "a fairly deep anti-Muslim reaction, which had only been strengthened by the fact that Muslim youth groups had been so active, whether autonomously or as agents of the army, in the killings" (Geertz, 1972:68). This was far from the case in Tegalroso.

Although there were $13 \mathrm{PKI}$ activists in Tegalroso who had been jailed for two to four years as tapol (from tahanan politik, political prisoners), no one was killed. All but one (who died after a two month long illness before this research commenced in the village) now live as ordinary villagers. The absence of killing in Tegalroso and other villages in the Magelang regency is attributable to the fact that there was no significant confrontation resulting in physical clashes between the PKI and the other political parties, especially the Muslim parties, as had occurred in other parts of Java during the two years before the coup (Walkin, 1969; Lyon, 1970; Mortimer, 1972).

By contrast, in Kanigoro, East Java, the Communists were reported to have seized the belongings of the Muslim students who were operating authorized training, bound their hands, and walked them six kilometers to a police station where they were turned in as subversives. The communists were also subsequently accused of entering a mosque with dirty feet, manhandling a Kyai, and trampling on the Qur'ân - by using their feet to pack the Qur'ân and other belongings of the students into sacks (Walkin, 1968:829830).

These kind of open attacks on religion and religious-based organizations did not take place in the Magelang regency, nor did the unilateral actions that were launched by PKI supporters in many other parts of Java (cf. Mortimer, 1972:40-55; Cribb, 1990:121-132). Hence, the hatred towards PKI members, especially on the part of the Muslims, was not serious enough to lead to mass killings as occurred elsewhere, such as in East Java (by the Muslims) and in Bali (by the Hindus). A former Ansor (NU youth organization) activist in 1965 even maintained that ex-PKI supporters in Tegalroso were only PKI copycats (PKI ikut-ikutan). 
All this resulted in relatively more moderate action against PKI supporters in the area. Thus, the following Geertz' statement, applicable elsewhere, does not describe the situation in Tegalroso: "many of the sort of people the Javanese call abangan were unwilling even to be formally regarded as Muslims - Muslim statistik", as a result of a deep antipathy towards Islam (1972:68). No one in Tegalroso left Islam.

Another reason why ex-tapol, like other villagers, retained their adherence to Islam was that they were more familiar with Islam than other religions. For example, an ex-tapol told me that he first learned about Christianity and Hinduism from preachers amongst the political prisoners. Yet, he was interested in neither. He found the Christian mode of praying very strange. In his words: "mosok nyembab Gusti Allob kok nyanyi!" (It is funny, isn't it, praying to God by singing!). He found Hinduism equally odd. "If I were a Hindu perhaps I would not dare to consume fish, chicken or lamb anymore; they may be reincarnations of my ancestors. And when I die I want my relatives to perform prayers and hold slametan for me as a Muslim." He then went on to say: "Although many people here do not implement the daily prayers (dereng nglampabi), their hearts would be hurt if they were regarded as non-Muslims. All the people here firmly believe in lât ilâha illâ Allâh Muhamad Rasûl Allâh (there is no god but Allah, the one God, and Muhammad is the Messenger of Allah)."

Hence, in a situation characterized by a widespread search for religious shelter (pelindung) (see Geertz, 1972:69), people in Tegalroso remained Muslims. To combat the accusation of atheism, all they needed was to intensify their participation in religious rituals, particularly the daily prayers. Many who previously did not pray then did so. Hence the provision of places of worship came to be felt to be an urgent need.

It would nonetheless be misleading to suggest that the process of 'santri-ization' in Tegalroso was a mere search for political shelter. In fact only one langgar (mBah Parto's langgar built in 1967) was built immediately after the events of 1965 . The two newest mosques (at Calonan and Tegal Watu), the building of which absorbed relatively more of the villagers' spirit and energy, were built in 1981 and 1984 , more than 15 years after the coup. Now they are also preparing to construct another new mosque. 
Thus, the new langgars and mosques are best understood as a reflection of a genuine religious resurgence among the villagers.

Pak Sarju, an alumnus of Tembarak Pesantren, Temanggung, who resides uxorilocally in Tegal Watu, says that when he first arrived there in 1976, he did not believed that this hamlet would possess a mosque such as that which currently exists. Learning that there were only 15 households who prayed regularly, he thought: "what was said by my fellow villagers is true, many people here are ex-PKI members who are far from religion." However, his impression then changed. Knowing that he was a pesantren graduate, his neighbors soon sought his religious advice. He then organized a weekly pengajian in the langgar. As a result, the number of those who prayed steadily increased. Pak Sarju remarked : "All the people here are Muslims. If many of them still do not pray or if they gamble, it is merely because in the past no one taught them religious teachings. But, in their hearts, actually they are already Muslims."

According to Pak Sarju it was in mid-1981 when more than 50 households were praying regularly that the idea of building a mosque in Tegal Watu arose. One evening during a pengajian Pak Jimat, a regular participant, asked the audience whether they wanted to follow the example of the Calonan people and build their own mosque. His question turned the pengajian into a forum to discuss the possibility of constructing a mosque in Tegal Watu. During that evening Pak Jimat himself donated some land for a site. When the idea was conveyed to the other villagers, they gave their full support and, following the example of Calonan, through weekly collections and gotong royong (mutual self-help), the people of Tegal Watu eventually finished the mosque in early 1984.

Now, every Friday the mosque is crowded with men and women attending the congregational noon prayer. Every Thursday evening Pak Sarju or Pak Rohadi, a religious teacher in the Tegalroso primary school, gives weekly pengajian for adult villagers in the mosque. Also, studying religion (ngaji) in the mosque between the mid-afternoon prayers ('asar) and sunset prayers (maghrib), has become a daily agenda (excluding Fridays) for children and teenagers.

The importance of this religious learning activity is appreciated even by those who do not pray. For example, one evening I 
accompanied Pak Lurah on a walk around Tegal Watu and we called in at Pak Seneng's house which also functions as a small shop (warung). Pak Lurah asked him why he had not enrolled his only son at the SMP (Sekolah Menengah Pertama - Secondary School). Pak Seneng replied that he had encouraged his son to do so, but he had refused to be enrolled and he did not want to force him. "Although my son will not continue his studies, I urged him to attend religious lessons in the mosque every afternoon." Pak Lurah thus commented, "What about yourself, have you begun to pray?" Pak Seneng replied:

I do not pray, but I hope that my son will not be like me. I did not finish primary school, my son finished it. This means that he has made progress. The same goes for religious matters. I never received a religious education, as a langgar existed here only after I got married. Now, the villagers here have established a mosque. This means that people here have made progress in the religious field. We also have Pak Sarju, a pious person (tiyang alim) who is willing to teach religion to our children without payment. I would not be thankful to Allah if I did not utilize this opportunity to encourage my son to learn to be a better Muslim than I.

Pak Seneng's wife, who was preparing to serve us tea and heard our talk, interrupted: "Badhèo larè kulo mbotèn dados tiyang pinter, ingkang penting rak uger mbotèn dados tiyang keblinger to Pak Lurab (Pak Lurah, although my son will not become a clever person, the most important thing is not to become one who goes astray, isn't it!)" In response to this Pak Lurah then suggested that Pak Seneng and his wife send their son to the Pabelan Pesantren, $15 \mathrm{Km}$ away. "In this pesantren children are educated to become people who are knowledgeable in religious matters and capable in practical knowledge such as farming and artisan works, and it does not cost much", Pak Lurah told them. Apparently both Pak Seneng and his wife were interested in Pak Lurah's suggestion: "I will discuss this with my son. If he agrees then we'll see Pak Lurah!"

On the way home, Pak Lurah told me that fifteen years ago he never imagined that his fellow villagers would be as religious as they are now: "Formerly, when I met people here they talked mostly about who won and lost in the gambling. They were far from religion. Now even those such as Pak Seneng, who don't pray, talk about the mosque and religious education for their children." 
Thus, although the foundation of a new langgar and mosques in Tegalroso cannot be isolated from the wider political situation, the phenomenon also genuinely reflects a religious resurgence among villagers.

\section{Conclusion}

To sum up, as we have seen, the 'New Order' government has emphasized political stability for the sake of economic development. This has been marked among other things by the ban on political party activities at the village level, and a strong commitment to religious life. Religious activities have therefore become the concern of all people regardless of political affiliation. As a result, as shown in Tegalroso, Islam has now regained an allembracing appeal and function for the villagers. Active participation of those who, in the past were the supporters of nonIslamic political parties, in the construction of mosques and other religious activities is a clear testimony to this process.

In other words, as can clearly be seen in Tegalroso, the santriabangan dichotomic approach is no longer relevant to an understanding of the religious life of Javanese Muslims.as

\section{References}

Benda, J.J., The Crescent and the Rising Sun (The Hague and Bandung: W. Van Hoeve Ltd, 1958).

Cribb, R. (ed.), The Indonesian Killings 1965-1966 (Clayton, Victoria: CSEAS, Monash University, 1991).

Feith, H., The Decline of Constitutional Democracy in Indonesia (Ithaca: Cornell University Press, 1962).

Geertz, C., The Religion of Java (New York: The Free Press of Glencoe, 1960). (27) (Autumn, 1972).

, "Religious Change and Social Order in Soeharto's Indonesia", Asia

Hefner, R.W., "Islamizing Java? Religion and Politics in Rural East Java", The Journal of Asian Studies, 45 (3) (1987).

Jay, R.R., Religion and Politics in Rural Central Java (Yale University: Southeast Asia Studies, 1963).

Lyon, M., Bases of Conflict in Rural Java (University of California: Centre for South and Southeast Asian Studies, 1970).

Mackie, J., "Indonesia Since 1945 - Problem of Interpretation", in B. Anderson and A. Kahin (ed.), Interpreting Indonesian Politics: Thirleen Contributions to the Debate (Ithaca: Cornell University, 1982). 
Mortimer, R., The Indonesian Communist Party and Land Reform 1959-1965

(Clayton, Victoria: CSEAS, Monash University, 1972).

Pigeaud, Th.G.Th., Literature of Java (The Hague: Martinus Nijhoff, 1967).

Ricklefs, M.C., "Six Centuries of Islamization in Java'", in N. Levtzion (ed.), Conversion to Islam (New York: Holmes \& Meier Publisher Inc. 1979).

Education Ltd., 1987).

Soejatno, "Revolution and Social Tensions in Surakarta 1945-1950" (translated by B. Anderson), Indonesia (17) (April 1974), pp. 99-111.

Suryadinata, L., "Indonesia's Political System: Continuity and Change", Contemporary Southeast Asia 9 (4) (March 1988).

Samson, A.A., "Army and Islam in Indonesia", Pasific Affairs 4 (4) (1971/1972), pp. 545-565.

Ward, K., The Election in Indonesia: An East Java Case Study, (Monash University: CSEAS, 1974).

Zuhri, Saifuddin, Berangkat Dari Pesantren (Jakarta: Gunung Agung, 1987).

Bambang Pranowo was the head of the Institute of Religious Research (Balai Penelitian Agama), the Department of Religious Affairs, the Republic of Indonesia. 